\author{
2021 Volume 7 Number 1 January-February
}

\title{
Cell pattern abnormalities in cervical pap smear in correlation with age and demography at a Tertiary care centre.
}

\author{
Selvi N. ${ }^{1}$, Shree R R. ${ }^{2 *}$, Prakashiny S. $^{3}$ \\ DOI: https://doi.org/10.17511/jopm.2021.i01.05 \\ 1 N. Thamarai Selvi, Assistant Professor, Department of Pathology, Shri Sathya Sai Medical College \& Research Institute, Sri Balaji \\ Vidyapeeth (SBV)( Deemed to be University), Ammapettai, Tamil Nadu, India. \\ 2* Revathi Shree R, Associate Professor, Department of Pathology, Shri Sathya Sai Medical College \& Research Institute, Sri Balaji \\ Vidyapeeth (SBV)( Deemed to be University), Ammapettai, Tamil Nadu, India. \\ 3 Prakashiny S, Associate Professor, Department of Pathology, Shri Sathya Sai Medical College \& Research Institute, Sri Balaji Vidyapeeth \\ (SBV)( Deemed to be University), Ammapettai, Tamil Nadu, India.
}

Introduction: Carcinoma Cervix is common all around the globe and ranked third amidst all malignancies among women. The cervical mucosa undergoes morphologic variation with age and practising cytopathologists is aware of these difference to make an accurate diagnosis. This study aimed to detect abnormal cervical epithelial cell patterns in a rural population and compare lesions or abnormal cell patterns among different age groups. Materials and Methods: This is a crosssectional, descriptive study conducted in a tertiary care centre at the Department of Pathology over 6 months. 408 women were included in the study. Data were entered in Microsoft Excel and analyzed in SPSS software. Results: Out of 408 women included in the study, the most common age group of the presentation was 31 to 40 years (36\%), followed by 20 to 30 years (24\%). NILMInflammatory was the most common finding (50\%), followed by NILM (36\%). The most common symptoms of presentation were Menstrual abnormalities (21\%), White discharge and pruritus $(18 \%)$. Findings in younger women were most commonly NILM-Inflammatory \& NILM whereas in the post-menopausal age group, ASCUS, LSIL \& HSIL. Conclusion: All women above 30 years of age should undergo routine cervical cancer screening, and should continue screening even in the perimenopausal and postmenopausal age. Most women who visited the gynaecology OPD were not aware of cervical cancer screening. Hence the general population has to be educated about the benefits of pap smear test through medical camps and awareness programs.

Keywords: Pap smear, NILM, NILM-Inflammatory smear

Corresponding Author

Revathi Shree R, Associate Professor, Department of Pathology, Shri Sathya Sai Medical College \& Research Institute, Sri Balaji Vidyapeeth (SBV)( Deemed to be University), Ammapettai, Tamil Nadu, India.

Email: mail2rrevathi@gmail.com
How to Cite this Article

Selvi NT, Shree R R, Prakashiny S. Cell pattern abnormalities in cervical pap smear in correlation with age and demography at a Tertiary care centre.. Trop J Pathol Microbiol. 2021;7(1):33-39.

Available From

https://pathology.medresearch.in/index.php/jopm/ar ticle/view/507
To Browse

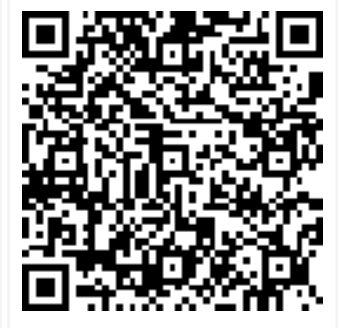

Manuscript Received 2020-12-24

Conflict of Interest No

Review Round 1
2021-12-31
Funding
Nil

Review Round 1

Nil

Review Round 2
2021-01-03
$\begin{gathered}\text { Ethical Approval } \\ \text { Yes }\end{gathered}$

Review Round 2

Yes
Review Round 3

Plagiarism X-checker $7 \%$
Accepted 2021-01-05

(c) 2021 by N. Thamarai Selvi, Revathi Shree R, Prakashiny S and Published by Siddharth Health Research and Social Welfare Society. This is an Open Access article licensed under a Creative Commons Attribution 4.0 International License https://creativecommons.org/licenses/by/4.0/ unported [CC BY 4.0]. 


\section{Introduction}

Carcinoma Cervix is common all around the globe and ranked third amidst all malignancies among women. $80 \%$ of cervical cancer are seen in developing countries, which is the most common cancer in woman [1]. In developing countries, the conventional Papanicolaou test is an important screening system for cervical cancer [2].

Recently cytological screening with pap smear combined with Human Papilloma Virus testing is being assessed as a screening test for cervical cancer in the developed countries. Similar to other DNA viruses, the presence of HPV is analyzed by DNA testing with a polymerase chain [3].

Cervical epithelial cell abnormalities in the pap smear represent a spectrum of intraepithelial lesions which varies from mild-to-severe dyskaryosis to invasive cancer [4]. The significance of these various lesions and the outcome of cervical pap smear with atypia have been elaborately analyzed $[5,6]$. Screening with Pap smear has been accompanied by a dramatic reduction in the incidence of invasive cervical cancer all over the world. As of now, two types of Pap tests are currently used: Conventional \& Liquid-based cytology.

Even though the liquid-based test has been widely used in developed countries, the conventional Pap test is the main screening system even now in developing. Numerous studies describe that majority of cervical cancer mortality all over the world is seen in developing countries $[7,8,9]$.

This is a challenge that occurred due to an ineffective cervical cancer screening system. Henceforth this is important to understand the spectrum of variations of epithelial cell abnormalities in Pap smear, in a developing country like India.

In the prospect of counselling women and to organize a public health system for Carcinoma Cervix screening by Pap smear examination, it is ideal to understand the distribution of the various spectrum of premalignant and malignant lesions [2]. This study has been undertaken to find out the prevalence of an abnormal Pap smear, in a tertiary hospital of a developing country, and to carry out a clinicopathological and demographical analysis for establishing the pattern of epithelial cell abnormality in a Pap smear.

\section{Materials and Methods}

This is a cross-sectional, descriptive study conducted in a tertiary care centre at the Department of Pathology over 6 months. A complete clinical history and demographic status of the patient undergoing pap smear was recorded as per the proforma, concerning the age at presentation, age at marriage, parity, complaints, first childbirth, socioeconomic status and literacy.

The inclusion criteria were: Symptomatic patients with normal cervix on clinical examination and symptomatic patients with a suspicious cervical lesion. Cases excluded from the study were pregnant women, patients who have undergone a hysterectomy.

Conventional pap smears were taken with the help of gynaecologists at the squamocolumnar junction using Ayer's spatula. Endocervical smears were made by rotating the endocervical brush. Two separate smears were made from the squamocolumnar junction and endocervical area on a single glass slide respectively. Immediately smears were fixed in 95\% Isopropyl alcohol for 30 minutes. Then Pap staining was done followed by slide interpretation. The pap smears were reported by adopting "The Revised Bethesda System of Classification ". Data were entered in Microsoft Excel and analyzed in SPSS software version 17.0. Confidentiality was maintained in this study as mentioned in the patient's consent forms.

\section{Results}

A total of 408 women have been included in the present study, out of which 98 women (24\%) were seen in the age group of 20-30 years. 148 women $(36 \%)$ were in the age group of 31 to 40 years. 90 women (22\%) were in the age group of 41 to 50 years. 36 women $(09 \%)$ were in the age group of 51 to 60 years. 36 women $(09 \%)$ were in the age group of $>60$ years ( Table No. 1 ).

Out of 408 women included in the study, 149 cases (36\%) were found to be Normal or Negative for Intraepithelial Lesion or Malignancy (NILM). 203 cases $(50 \%)$ were found to have Inflammatory Pathology and reported as Negative for Intraepithelial Lesion or Malignancy - Inflammatory (NILM - Inflammatory). 20 cases (05\%) were found to have Atrophic Changes. 6 cases $(1.5 \%)$ have been reported as Atypical Squamous Cells of Undetermined Significance (ASCUS). 
12 cases $(03 \%)$ have been reported as Low-Grade Squamous Intraepithelial Lesion (LSIL). 2 cases $(0.5 \%)$ have been reported as High-Grade Squamous Intraepithelial Lesion (HSIL). 16 cases (04\%) have been reported as Insufficient or Inadequate Sample ( Table No.2).

Out of 408 patients included in the study, NILM was found in 149 women, out of which 32 cases (21\%) among the age group of 20 to 30 years, 46 cases ( $31 \%$ ) in the age group of 31 to 40 years, 38 cases $(26 \%)$ in the age group of 41 to 50 years, 20 cases $(13 \%)$ among the age group of 51 to 60 years and 13 cases $(09 \%)$ in the age group above 60 years. NILM - Inflammatory has been reported in a total of 203 women, out of which 54 cases $(27 \%)$ in the age group of 20 to 30 years, 55 cases $(27 \%)$ in the age group of 31 to 40 years, 40 cases $(20 \%)$ in the age group of 41 to 50 years, 32 cases (16\%) in the age group of 51 to 60 years and 22 cases (10\%) in the age group of $>60$ years of age. Atrophic smear has been reported in 20 cases, out of which 9 cases $(45 \%)$ were in the age group of 51 to 60 years and 11 cases $(55 \%)$ were in the age group $>60$ years of age. Inadequate was reported in 16 cases, out of which 3 cases (19\%) were in the age group of 20 to 30 years, 4 cases (25\%) were in the age group of 31 to 40 years, 4 cases $(25 \%)$ were in the age group of 41 to 50 years, 2 cases (12\%) were in the age group of 51 to 60 years and 3 cases (19\%) were in the age group of $>60$ years of age. Out of 6 cases reported as ASCUS, 2 cases (33\%) were seen in the age group of 41 to 50 years, 3 cases $(50 \%)$ were seen in the age group of 51 to 60 years and 1 case $(17 \%)$ were seen in the age $>60$ years of age. Out of 12 cases reported as LSIL, 1 case ( $8 \%$ ) was seen in the age group of 31 to 40 years, 3 cases $(25 \%)$ were seen in the age group of 41 to 50 years, 6 cases ( $50 \%$ ) were seen in the age group of 51 to 60 years and 2 cases(17\%) were seen above 60 years of age. Out of 2 cases reported as HSIL, both the cases (100\%) were seen in the age group of 51 to 60 years (Table No.3).

Complaints with which most of the patients came were for routine Screening, menstrual abnormalities, white discharge, pruritus and pain abdomen. Out of 408 women included in this study, 140 (34\%) came for routine screening, 86 (21\%) came for menstrual abnormalities, 74 (18\%) came with complaints of white discharge, $2(0.5 \%)$ came for postmenopausal bleeding, 74 women (18\%) came for pruritus and 32 women (8.5\%) came with pain abdomen.
Among 149 cases diagnosed as NILM, 48 (32\%) presented for routine screening, 30 women (20\%) had menstrual abnormalities, 14 women (10\%) came with white discharge, 33 women (22\%) came with pruritus and 24 women (16\%) came with pain abdomen. Out of 203 cases diagnosed as NILMInflammatory, 62 women (30\%) were asymptomatic, 40 women (20\%) came with menstrual abnormalities, 28 women (14\%) came with white discharge, 54 women $(27 \%)$ came with pruritus and 19 women (9\%) came with pain abdomen. Out of 20 cases reported as Atrophic, 2 women (10\%) were asymptomatic, 4 women (20\%) had menstrual abnormalities, 2 women (10\%) had white discharge, 8 women (40\%) had pruritus and 4 women $(20 \%)$ had pain abdomen. Out of 6 women diagnosed with ASCUS, 2 (33\%) had white discharge, 1 (17\%) had pruritus and 3 (50\%) had pain abdomen. Out of 12 cases diagnosed as LSIL, 4 (33\%) had white discharge, $6(50 \%)$ had pruritus and $2(17 \%)$ had pain abdomen. Out of 2 cases diagnosed as HSIL, both the women presented with post-menopausal bleeding. Out of 16 cases diagnosed as Inadequate sample, 4 (25\%) were asymptomatic, 3 (19\%) had menstrual abnormalities, 2 (12\%) had white discharge, 4 $(25 \%)$ had pruritus and $3(19 \%)$ had pain abdomen (Table No.4)

Out of 203 cases diagnosed as NILM-Inflammatory, 132 patients $(65 \%)$ had Bacterial Vaginosis, 08 cases $(04 \%)$ had candidiasis, 02 cases $(01 \%)$ had Trichomonas infection, 02 cases (01\%) had chlamydiosis, 04 patients (02\%) had Leptothrix and 55 patients $(27 \%)$ had non-specific findings (Table No.5).

Out of 149 cases diagnosed as NILM, 97 women $(65 \%)$ were in the pre-menopausal age group, 10 cases showed koilocytic change and 52 women (35\%) were in the post-menopausal age and 6 cases showed koilocytic change. Out of 203 cases diagnosed as NILM-Inflammatory, 129 women (64\%) were in the age group of pre-menopausal, 12 showed koilocytic change and 74 women (36\%) were in the post-menopausal age group and 4 showed koilocytic change. Out of 20 cases diagnosed as Atrophy, all were in the postmenopausal age among which 1 showed koilocytic change. Out of 6 cases diagnosed as ASCUS, 2 women $(33 \%)$ were in the pre-menopausal age group and 4 women $(67 \%)$ were in the postmenopausal age group amidst which 1 showed koilocytic change. 
Out of 12 cases diagnosed as LSIL, 2 women (17\%) were in the pre-menopausal age group, in which 2 showed koilocytic change and 10 women (83\%) were in the post-menopausal age group, in which 4 showed koilocytic change. Out of 2 cases diagnosed as HSIL, both were post-menopausal and showed no koilocytic change (Table No.6)

Out of 408 cases included in the study, per speculum findings were noted. 132 women (32\%) had healthy looking cervix, 74 women (18\%) had white discharge per vaginum, 12 women (3.5\%) had hypertrophied cervix, 118 women (29\%) had cervical erosion, 08 women (02\%) had ectropion of cervix, 02 women $(0.5 \%)$ showed cervical bleeding and 62 women (15\%) had Cystocele (Table No.7).

\section{Table-1: Age Distribution}

\begin{tabular}{|l|l|l|l|}
\hline S.No. & Age in Years & Number & Percentage(\%) \\
\hline
\end{tabular}

\begin{tabular}{|l|l|l|l|}
\hline 1. & $20-30$ & 98 & $24 \%$ \\
\hline 2. & $31-40$ & 148 & $36 \%$ \\
\hline 3. & $41-50$ & 90 & $22 \%$ \\
\hline 4. & $51-60$ & 09 & $09 \%$ \\
\hline 5. & $>60$ & 09 & $09 \%$ \\
\hline 6. & Total & 408 & $100 \%$ \\
\hline
\end{tabular}

Table-2: Spectrum of Pap Smear Abnormalities

\begin{tabular}{|l|l|l|l|}
\hline S.No. & \multicolumn{1}{|c|}{ Finding } & \multicolumn{1}{|c|}{ Number } & \multicolumn{1}{|c|}{ Percentage(\%) } \\
\hline 1. & NILM & 149 & $36 \%$ \\
\hline 2. & NILM - Inflammatory & 203 & $50 \%$ \\
\hline 3. & Atrophy & 20 & $05 \%$ \\
\hline 4. & ASCUS & 06 & $1.5 \%$ \\
\hline 5. & LSIL & 12 & $03 \%$ \\
\hline 6. & HSIL & 02 & $0.5 \%$ \\
\hline 7. & Carcinoma & - & $00 \%$ \\
\hline 8. & Inadequate Sample & 16 & $04 \%$ \\
\hline 9. & Total & 408 & $100 \%$ \\
\hline
\end{tabular}

Table-3: Correlation of Age with Various Lesions

\begin{tabular}{|c|c|c|c|c|c|c|c|c|c|c|c|c|c|c|c|c|}
\hline \multirow[t]{2}{*}{ Age } & \multicolumn{2}{|c|}{ NILM } & \multicolumn{2}{|c|}{ NILM- Inflammatory } & \multicolumn{2}{|c|}{ Atrophic } & \multicolumn{2}{|c|}{ Inadequate } & \multicolumn{2}{|c|}{ AScus } & \multicolumn{2}{|c|}{ LSIL } & \multicolumn{2}{|c|}{ HSIL } & \multicolumn{2}{|c|}{ TOTAL } \\
\hline & No. & $\%$ & No. & $\%$ & No. & $\%$ & No. & $\%$ & No. & $\%$ & No. & $\%$ & No. & $\%$ & No. & $\%$ \\
\hline $20-30$ & 32 & 21 & 54 & 27 & - & - & 03 & 19 & - & - & - & - & - & - & 89 & 22 \\
\hline $31-40$ & 46 & 31 & 55 & 27 & - & - & 04 & 25 & - & - & 01 & 08 & - & - & 106 & 26 \\
\hline $41-50$ & 38 & 26 & 40 & 20 & - & - & 04 & 25 & 02 & 33 & 03 & 25 & - & - & 87 & 21 \\
\hline $51-60$ & 20 & 13 & 32 & 16 & 09 & 45 & 02 & 12 & 03 & 50 & 06 & 50 & 02 & 100 & 74 & 18 \\
\hline$>60$ & 13 & 09 & 22 & 10 & 11 & 55 & 03 & 19 & 01 & 17 & 02 & 17 & - & - & 52 & 13 \\
\hline Total & 149 & 100 & 203 & 100 & 20 & 100 & 16 & 100 & 06 & 100 & 12 & 100 & 02 & 100 & 408 & 100 \\
\hline
\end{tabular}

\section{Table-4: Correlation of Clinical Features with Various Lesions}

\begin{tabular}{|c|c|c|c|c|c|c|c|c|c|c|c|c|c|c|c|c|}
\hline \multirow[t]{2}{*}{ Clinical Features } & \multicolumn{2}{|c|}{ NILM } & \multicolumn{2}{|c|}{ NILM-Inflammatory } & \multicolumn{2}{|c|}{ Atrophic } & \multicolumn{2}{|c|}{ Inadequate } & \multicolumn{2}{|c|}{ ASCUS } & \multicolumn{2}{|c|}{ LSIL } & \multicolumn{2}{|c|}{ HSIL } & \multicolumn{2}{|c|}{ TOTAL } \\
\hline & No. & $\%$ & No. & $\%$ & No. & $\%$ & No. & $\%$ & No. & $\%$ & No. & $\%$ & No. & $\%$ & No. & $\%$ \\
\hline Routine Screening & 48 & 32 & 62 & 30 & 02 & 10 & 04 & 25 & L & - & - & - & - & . & 140 & 34 \\
\hline Menstrual Abnormalities & 30 & 20 & 40 & 20 & 04 & 20 & 03 & 19 & - & - & - & - & - & - & 86 & 21 \\
\hline White Discharge & 14 & 10 & 28 & 14 & 02 & 10 & 02 & 12 & 02 & 33 & 04 & 33 & - & - & 74 & 18 \\
\hline Postcoital Bleed & - & - & - & - & - & - & - & - & - & - & - & - & 02 & 100 & 02 & 0.5 \\
\hline Pruritus & 33 & 22 & 54 & 27 & 08 & 40 & 04 & 25 & 01 & 17 & 06 & 50 & - & - & 74 & 18 \\
\hline Pain Abdomen & 24 & 16 & 19 & 9 & 04 & 20 & 03 & 19 & 03 & 50 & 02 & 17 & - & - & 32 & 8.5 \\
\hline Total & 149 & 100 & 203 & 100 & 20 & 100 & 16 & 100 & 06 & 100 & 12 & 100 & 02 & 100 & 408 & 100 \\
\hline
\end{tabular}

Table-5: Distribution of Inflammatory Smears

\begin{tabular}{|l|l|l|l|}
\hline S.No. & \multicolumn{1}{|c|}{ Findings } & \multicolumn{1}{c|}{ Number } & \multicolumn{1}{c|}{ Percentage(\%) } \\
\hline 1. & Bacterial Vaginosis & 132 & 65 \\
\hline 2. & Candidiasis & 08 & 04 \\
\hline 3. & Trichomonas & 02 & 01 \\
\hline 4. & Chlamydia & 02 & 01 \\
\hline 5. & Leptothrix & 04 & 02 \\
\hline 6. & Non-Specific & 55 & 27 \\
\hline 7. & Total & 203 & 100 \\
\hline
\end{tabular}

Table-6: Comparison of Lesions in Pre- and

\section{Post-Menopausal Women}

\begin{tabular}{|l|l|l|l|l|l|l|l|l|}
\hline Lesions & \multicolumn{2}{|c|}{ Pre-menopausal Women } & \multicolumn{3}{|l|}{ Post-menousal Women } & Total \\
\cline { 1 - 5 } Findings & No. & $(\%)$ & Koilocytic Status & No. & $(\%)$ & Koilocytic Status & \\
\hline NILM & 97 & 65 & 10 & 52 & 35 & 06 & 149 \\
\hline $\begin{array}{l}\text { NILM- } \\
\text { Inflamm } \\
\text {-atory }\end{array}$ & 129 & 64 & 12 & 74 & 36 & 04 & 203 \\
\hline Atrophy & - & - & - & & & & \\
\hline ASCUS & 02 & 33 & - & 20 & 100 & 07 & 20 \\
\hline LSIL & 02 & 17 & 02 & 04 & 67 & 01 & 06 \\
\hline HSIL & - & - & - & 10 & 83 & 04 & 12 \\
\hline
\end{tabular}


Table-7 Distribution of Perspeculum Findings

\begin{tabular}{|l|l|l|l|}
\hline S.No. & \multicolumn{1}{|c|}{ Findings } & Number & \multicolumn{1}{|c|}{ Percentage(\%) } \\
\hline 1. & Healthy Looking Cervix & 132 & 32 \\
\hline 2. & White Discharge PV & 74 & 18 \\
\hline 3. & Hypertrophied Cervix & 12 & 3.5 \\
\hline 4. & Cervical Erosion & 118 & 29 \\
\hline 5. & Ectropion of Cervix & 08 & 02 \\
\hline 6. & Bleeds on Touch & 02 & 0.5 \\
\hline 7. & UV Prolapse/Cystocele & 62 & 15 \\
\hline 8. & Total & 408 & 100 \\
\hline
\end{tabular}

\section{Discussion}

It is noticed in this study that most women visit Gynecology OPD for infections and menstrual abnormalities. The spectrum of Epithelial cell abnormalities has been focussed on in this study. A total of 408 women have been included in the study, out of which the most common age group was 31 to 40 years $(36 \%)$, followed by 20 to 30 years $(24 \%)$, followed by 41 to 50 years (22\%). In a study conducted by Pun Gurung Rashmey et al, it was found that the most common age of presentation was 3039 years (29\%), followed by 40 to 49 years $(27 \%)$, followed by 50 to 59 years $(19 \%)$. The age distribution is almost the same compared to the present study $[10,11]$.

Out of 408 cases in the study, 203 cases (50\%) were found to have NILM - Inflammatory, followed by 149 cases (36\%) were diagnosed as NILM. In a study conducted by Das et al and Bhagya Lakshmi et al, similar findings were observed $[11,12]$.

Considering the age-wise distribution of various lesions, in the age group of 20 to 40 years, the most common lesion was found to be NILM Inflammatory $(54 \%)$, followed by NILM (52\%). In the age group of 41 to 50 years, the most common finding is NILM, followed by NILM - Inflammatory, followed by ASCUS. Among the age group of 51 to 60 years, ASCUS (50\%) was more common, followed by LSIL (50\%), followed by HSIL (both the cases), followed by Atrophic (45.

In women $>60$ years of age, the most common findings were ASCUS (17\%), followed by LSIL $(17 \%)$ and Atrophic (55\%) and few cases of NILM in the present study. It is hypothesized that NILM and NILM-Inflammatory were common in the younger ages and ASCUS, LSIL, HSIL and malignancies are more common in the elderly age group ( $>50$ years of age) and similar findings were also found in a few of the other studies $[10,11]$.
Hence, women should be screened for a pap smear and subjected to examination with increasing age.

Most patients who came for routine screening were found to be NILM. When women presented with menstrual abnormalities or asymptomatic, they were found to have NILM-Inflammatory. Most women who presented with pruritus was found to have atrophic smears. This may be due to age factors and decreased secretions which would have led to pruritus. Most patients who presented with Pain abdomen, white discharge and pruritus were found to have ASCUS \& LSIL.

2 patients who presented with postmenopausal bleeding were found to have HSIL. In a study conducted by Pun Gurung et al, it was observed that most women ( $86 \%$ ) came for routine screening, $9 \%$ came for white discharge, $2 \%$ for pruritus and $3 \%$ for pain abdomen [10]. In a study conducted by Pushpa Latha et al, it was found that $36 \%$ had white discharge, $25 \%$ of women had pain abdomen, $15 \%$ were asymptomatic, $12 \%$ had menstrual abnormalities, $8 \%$ had pruritus and $4 \%$ presented with post-menopausal bleeding. It was observed in that study that women who presented with Irregular bleeding were found to have ASCUS \& LSIL [13].

Among the 203 cases diagnosed as NILMInflammatory, predominant women were found to have Bacterial Vaginosis (65\%), followed by Nonspecific findings $(27 \%)$, Candida $(4 \%)$, Leptothrix $(02 \%)$, Trichomonas (1\%) and Chlamydia (1\%). Findings in this study were almost similar to the study done by Pun Gurung Rashmey et al [10].

It was observed that NILM \& NILM-Inflammatory were more common in the premenopausal age group and Atrophy, ASCUS, LSIL \& HSIL are more common in the postmenopausal age group. Almost similar findings were seen in a few other studies as well $[14,15,16]$.

Regarding the per speculum findings, healthylooking cervix was seen in $32 \%$, Cervical erosion in $29 \%$, followed by white discharge per vaginum in 18 $\%$, UV prolapse in $15 \%$, hypertrophied cervix in 3.5 $\%$, Ectropion of cervix in $02 \%$ and bleeding in 0.5 $\%$ in the present study. In a study conducted by Pushpa et al, Healthy looking cervix is seen in $26 \%$, white discharge in $29 \%$, hypertrophied cervix in 11 $\%$, Cervical erosion in $19 \%$, Ectropion of cervix in $06 \%$, Bleeding in $05 \%$ and UV prolapse in $4 \%$ [13]. 
Table-8: Correlation of Results of Present Study with Other Studies

\begin{tabular}{|l|l|l|l|l|l|l|l|l|}
\hline \multicolumn{1}{|c|}{ Author Name } & \multicolumn{1}{|c|}{ No. of Cases } & \multicolumn{1}{|c|}{ NILM } & NILM- Inflammatory & Atrophic & ASCUS & \multicolumn{1}{|c|}{ LSIL } & HSIL & Malignancy \\
\hline Present Study & 408 & $36 \%$ & $50 \%$ & $05 \%$ & $1.5 \%$ & $3 \%$ & $0.5 \%$ & - \\
\hline Morris E et al & 271 & $32 \%$ & $48 \%$ & - & $12.2 \%$ & - & $8.4 \%$ & - \\
\hline Parate S N et al & 2544 & $30 \%$ & $57.7 \%$ & - & - & $0.25 \%$ & $0.94-2.06 \%$ & - \\
\hline Kaustubh et al & 610 & $45 \%$ & $50.1 \%$ & - & $3.27 \%$ & - & $2.94 \%$ & $0.65 \%$ \\
\hline Kapila K et al & 86,434 & $96.09 \%$ & & - & $2.2 \%$ & $08 \%$ & $1.2 \%$ & $0.1 \%$ \\
\hline Ranabhat S K et al & 880 & $72 \%$ & $26 \%$ & - & $0.23 \%$ & $0.23 \%$ & $1.02 \%$ & $0.23 \%$ \\
\hline Urmila B et al & 1699 & $91.81 \%$ & & - & $0.18 \%$ & $0.12 \%$ & $8.54 \%$ & $0.35 \%$ \\
\hline Magdy H B et al & 624 & $90.71 \%$ & & $0.34 \%$ & $3.59 \%$ & $0.09 \%$ & $0.77 \%$ & $0.51 \%$ \\
\hline Syed S A et al & 240 & $15 \%$ & $75.8 \%$ & $1.3 \%$ & $3.3 \%$ & $1.3 \%$ & $4.5 \%$ & - \\
\hline Pun R G et al & 1999 & $54 \%$ & $21.96 \%$ & $15.5 \%$ & $4.5 \%$ & $0.25 \%$ & $1 \%$ & $0.2 \%$ \\
\hline
\end{tabular}

Similar results were observed in the study by Morris et al Kaustubh et al and Bhavika K. $[17,18]$. When a mass is identified in colposcopy, clinicians went directly for biopsy instead of Pap smear examination and this could be the probable reason for no malignancy found in this study in Pap smear.

\section{Conclusion}

Pap smear screening protocol is a simple, economical, useful tool in detecting precancerous cervical epithelial lesions. It should be used widely as a routine screening procedure to reduce morbidity, and mortality.

All women above 30 years of age should undergo routine cervical cancer screening, and should continue screening even in the perimenopausal and postmenopausal age.

\section{What does the study add to the existing knowledge?}

Pap test is considered as the gold standard for Cervical Cancer screening programs. Also if a Pap test is combined with an HPV DNA test, the ability to detect any cervical pathology can be improved. Most women who visited the gynaecology OPD were not aware of cervical cancer screening.

Hence the general population has to be educated about the benefits of pap smear test through medical camps and awareness programs.

\section{Author's contribution}

Dr. N. Thamarai Selvi: Concept

Dr. Revathi Shree R: Study design

Dr. Prakashiny S: Manuscript preparation

\section{Reference}

01. Tamboli GD, et al. Accuracy of cytological findings in abnormal cervical smear by cytohistological comparison. J Med Educat Res. 2013;3(2)19-24.

[Crossref]

02. Banik U, Bhattacharjee P, Ahamad SU, Rahman Z. Pattern of epithelial cell abnormality in Pap smear- A clinicopathological and demographic correlation. Cyto Journal. 2011;8;8. doi: $10.4103 / 1742-6413.80527$ [Crossref]

03. Adhikary AK, Banik U, Numaga J, Suzuki E, Inada $\mathrm{T}$, Okabe $\mathrm{N}$. Heterogeneity of the fibre sequence in subgenus $\mathrm{C}$ adenoviruses. J Clin Pathol. 2004;57(6)612-7.

doi: $10.1136 /$ jcp.2003.014944 [Crossref]

04. Toews HA. The abnormal pap smear- A rationale for follow up. Can Fam Physician. 1983;29;759-

62.

[Crossref]

05. Elmslie TJ. The pap smear and cervical cancer screening. Can Fam Physician. 1987;33;131-7. [Crossref]

06. Chhieng DC, Roberson J, Gidley J, Eltoum I. Bethesda 2001- Impact on the reporting of gynecologic cytology. Acta Cytol. 2004;48;35562.

[Crossref]

07. Stewart BW, Kleihues P. World Cancer Report. Lyon- IARC Press. 2003.

[Crossref] 
08. Suba EJ, Raab SS. Viet/American Cervical Cancer Prevention Project, Papanicolaou screening in developing countries- An idea whose time has come. Am J Clin Pathol. $2004 ; 121 ; 315-20$.

[Crossref]

09. Suba EJ, Murphy SK, Donnelly AD, Furia LM, Huynh ML, Raab SS. Systems analysis of realworld obstacles to successful cervical cancer prevention in developing countries. Am J Public Health. 2006;96;480-7.

[Crossref]

10. Pun RG, Shrestha J, Awale PJ, Chitrakar N, Jha $\mathrm{R}$, Khadka SS. Cytological pattern of cervical pap smears. J Pathol Nep. 2018;8;1280-4. [Crossref]

11. Das D, Kar A, Rath S, Baliarsingh SK, Prusty D, Dash AK. Cytological pattern of Papanicolaou smears and detection of cervical cancers- An experience from a tertiary care centre of eastern zone of India. Oncol J India. $2018 ; 2 ; 25-$ 8.

[Crossref]

12. Atla BL, Uma $P$, Shamili M, Kumar SS. Cytological patterns of cervical pap smears with histopathological correlation. Int J Res Med Sci. 2015;3(8)1911-6.

[Crossref]

13. Sachan $P L$, Singh $M$, Patel $M L$, Sachan R. A Study on Cervical Cancer Screening Using Pap Smear Test and Clinical Correlation. Asia Pac J Oncol Nurs. 2018;5;337-41.

[Crossref]
14. Aytekin Tokmak, Ali Irfan Guzel, Emre Ozgu, Murat Oz, Serap Akbay, Salim Erkaya, Tayfun Gungor. Clinical Significance of Atypical Squamous Cells of Undetermined Significance in Detecting Preinvasive Cervical Lesions in PostMenopausal Turkish Women. Asian Pac J Cancer Prev. 15(16)6639-6641.

[Crossref]

15. Akshatha C, Arul P, Shetty S. Prevalence and comparison of cervical cytology abnormalities in postmenopausal and elderly women- A experience from tertiary care hospital. J MedSoc 2017;31:23-7.

[Crossref]

16. Misra JS, Srivastava AN, Zaidi ZH. Cervical cytopathological changes associated with onset of menopause. J Mid-life Health. 2018;9;180-4. [Crossref]

17. Kaustubh Mulay, Meenakshi Swain, Sushma Patra SG. A comparative study of cervical smears in an urban Hospital in India and a population-based screening program in MauritiusNo Title. Indian J Pathol Microbiol. 2009;52;34-7.

[Crossref]

18. Bhavika K, Vaghela VKV PMS. Analysis of abnormal cervical cytology in Papanicolaou smears at tertiary care center - A retrospective study. Int J Biomed Adv Res. 2014;5;47-9. [Crossref] 